\title{
Association of HCV with diabetes mellitus: an Egyptian case-control study
}

Eman I Elhawary ${ }^{1 *}$, Gamal F Mahmoud', Mai A El-Daly², Fatma A Mekky ${ }^{3}$, Gamal G Esmat ${ }^{4}$ and Mohamed Abdel-hamid²

\begin{abstract}
Background: The highest Hepatitis C Virus (HCV) prevalence in the world occurs in Egypt. Several studies from different parts of the world have found that 13\% to 33\% of patients with chronic HCV have associated diabetes, mostly type II Diabetes Mellitus (DM). In Egypt the prevalence of DM is $25.4 \%$ among HCV patients. Therefore, it is important to identify the magnitude of the problem of diabetes in order to optimize the treatment of chronic hepatitis $C$.

Methods: The objective of this case-control study was to evaluate the prevalence of DM and other extrahepatic (EH) manifestations among patients with different HCV morbidity stages including asymptomatic, chronic hepatic and cirrhotic patients. In this study, $289 \mathrm{HCV}$ patients older than 18 were selected as cases. Also, 289 healthy controls were included. Laboratory investigations including Liver Function tests (LFT) and blood glucose level were done. Also serological assays including cryoglobulin profile, rheumatoid factor, antinuclear antibody, HCV-PCR were performed.
\end{abstract}

Results: Out of $289 \mathrm{HCV}$ cases, 40 (13.84\%) were diabetic. Out of 289 healthy controls, 12 (4.15\%) were diabetic. It was found that the diabetic HCV group mean age was [48.1 ( \pm 9.2)]. Males and urbanians represented $72.5 \%$ and $85 \%$ respectively. Lower level of education was manifested in $52.5 \%$ and $87.5 \%$ were married. In the nondiabetic HCV group mean age was [40.7 ( \pm 10.4)]. Males and urbanians represented $71.5 \%$ and $655 \%$ respectively. secondary and higher level of education was attained in $55.4 \%$ and $76.7 \%$ were married. Comparing between the diabetic HCV group and the non diabetic HCV group, age, residence and alcohol drinking were the only significant factors affecting the incidence of diabetes between the two groups. There was no significant difference regarding sonar findings although cirrhosis was more prevalent among diabetic HCV cases and the fibrosis score was higher in diabetic HCV patients than among the non diabetic HCV cases.

Conclusion: The diabetic patients in the HCV group were older, more likely to have a history of alcohol drinking than the non diabetic HCV cases. Age and alcohol drinking are factors that could potentially contribute to the development of type 2 diabetes. Logistic regression analyses showed that age and residence in urban regions were the predictive variables that could be associated with the presence of diabetes. Alcohol consumption was not a significant predictive factor.

\section{Background}

The highest Hepatitis C Virus (HCV) prevalence in the world occurs in Egypt at an estimated 12\% among the general population [1] and reaches $40 \%$ in persons 40 years of age and above in rural areas [2]. HCV Genotype 4 is the predominant genotype being isolated from up to

\footnotetext{
* Correspondence: emanacy@yahoo.com

'Microbiology Department, Faculty of Pharmacy, Minia University, Minia, Egypt

Full list of author information is available at the end of the article
}

91\% of HCV-infected persons in Egypt [3]. The origin of the HCV epidemic in Egypt has been attributed to intravenous schistosomiasis treatment in rural areas in the 1960s-70s [4].

Although $\mathrm{HCV}$ targets at the liver, it has become interestingly evident that $\mathrm{HCV}$ can induce diseases of many organs. Cacoub et al. [5] reported that $38 \%$ of patients with $\mathrm{HCV}$ would manifest at least one extrahepatic manifestation during the illness.

\section{() Biomed Central}


Extrahepatic (EH) manifestations associated with $\mathrm{HCV}$ infection include endocrinological manifestations such as diabetes mellitus (DM) [6] and thyroiditis [7], rheumatologic manifestations such as arthralgias, arthritis [8] and mixed cryoglobulinemia [9]. The prevalence of clinically significant $\mathrm{EH}$ manifestations is relatively low, but can be associated with significant morbidity and even mortality. An awareness and recognition of these manifestations is of paramount importance in facilitating early diagnosis and management of these complications [10].

Type 2 diabetes (T2D) is a major public health problem worldwide [11] as people become more obese and live a more sedentary lifestyle [12]. This is in agreement with studies on T2D in noninfected individuals as well as patients infected with other HCV genotypes. The following risk factors are strongly associated with T2D: family history, body fat distribution, age, sex, smoking, and physical activity [13].

Several studies from different parts of the world have found that $13 \%$ to $33 \%$ of patients with chronic $\mathrm{HCV}$ have associated diabetes, mostly type II DM [14]. Diabetes was more frequent in patients having liver cirrhosis than those having chronic hepatitis [15]. Thus DM appears to be a unique $\mathrm{EH}$ manifestation of chronic HCV infection [16].

In Egypt the prevalence of DM was $25.4 \%$ among HCV patients [17]. Chronic hepatitis $C$ patients are three times more likely to develop DM than HCV seronegative patients $[17,14]$. Therefore, it is important to identify the magnitude of the problem of diabetes in order to optimize the treatment of chronic hepatitis $\mathrm{C}$.

The objective of this study was to evaluate the prevalence of DM and other EH manifestations among patients with different $\mathrm{HCV}$ morbidity stages including asymptomatic, chronic hepatic and cirrhotic patients age and sex matched.

\section{Patients and methods Study design}

The current research represents a case control study where patients with chronic $\mathrm{HCV}$ infection attending the outpatient clinic of Kasr El-Aini Hospital, Cairo University (KAH), National Hepatology and Tropical Medicine Research Institute (NHTMRI) and Viral Hepatitis Research Laboratory (VHRL) were interviewed. Patients were subjected to a questionnaire to screen those having EH manifestations and general examination. Patients were referred to rheumatologist, dermatologist for further assessment according to their clinical complaints. Laboratory investigations included complete blood picture, liver function tests and blood glucose. Abbott AxSYM System HCV version 3.0 was used for HCV Ab detection followed by In-house RT-PCR [18] for confirmation. Liver function tests (LFT) were carried out using Beckman Synchron CX4 Delta Clinical System (U.S.A.). Serological assay included cryoglobulin profile, rheumatoid factor, antinuclear antibody and HCV-PCR to assess viral load. Abdominal ultrasonography and biopsy was available from some of the patients.

Only HCV patients who were elder than 18 years and had their antibody profile positive for $\mathrm{HCV}$ were included as cases. Patients with decompensated liver disease, cancer, on interferon therapy, having end stage renal disease or coexisting viral infection like hepatitis B surface antigen positive patients, pregnant females were excluded from the research. Controls were with normal liver function tests, no serological evidence of HCV and no recent illness.

Defining type 2 diabetes was done according to the American Diabetes Association guidelines (2008)[19]. The current research was approved by the ethics committee of the NHTMRI. All patients gave informed written consents prior to participation and the study was conducted in accordance with Helsinki declaration.

\section{Statistical Analysis}

Comparisions between groups (cases and controls) were done using the Student's $t$ test for continuous variables and $\mathrm{x}^{2}$ test was used for nominal categorical variables. Continuous variables were summarized as mean \pm SD and categorical variables as frequency and percentage, unless otherwise stated.

All analyses were performed with SPSS software for Windows, version 13 (SPSS Inc., Chicago, IL). Correlation was determined by Pearson's linear regression analysis. All $P$ values are based on a two-sided test of statistical significance. $P$ value of $\leq 0.05$ will be considered as significant. Logistic regression analyses were used to evaluate the predictive variables that could be associated with the presence of diabetes.

\section{Results}

\section{I-HCV cases}

The mean age of cases ( \pm Standard deviation) was 41.7 ( \pm 10.6 ) with age range 19 to 65 years old (Table 1 ). $71.6 \%$ were males and $28.4 \%$ females. Over two-thirds (68.2\%) of cases were from urban regions with $45.7 \%$ of them did not complete their secondary education. Regarding their occupation, most of the study sample were skilled workers $(29.1 \%)$, employees $(22.8 \%)$, housewives (20.4\%), students (1.0\%) and others (26.9\%).21.4\% of them were current smokers, $5.2 \%$ were shisha smokers and 7.0\% drinked alcohol.

At least one EH manifestation was shown in $63.3 \%$ of HCV cases. Cryoglobulinemia was found positive in 22 patients $(7.6 \%)$. Rheumatologic manifestations were in $18.4 \%$ and dermatologic manifestations in $9.6 \%$ of the 
Table 1 Sociodemograhic characteristics and special habits of chronic hepatitis $C$ cases

\begin{tabular}{ll}
\hline Characteristic & $\begin{array}{l}\text { HCV cases } \\
\mathbf{N}=\mathbf{2 8 9} \\
\text { No (\%) }\end{array}$ \\
\hline Age (years) & $41.7 \pm 10.6$ \\
-Mean \pm SD & $19-65$ \\
-Range & \\
\hline Gender & $207(71.6)$ \\
-Male & $82(28.4)$ \\
-Female & \\
\hline Residence & $197(68.2)$ \\
-Urban & $92(31.8)$ \\
-Rural & \\
\hline Level of education & $132(45.7)$ \\
-Less than secondary & $157(54.3)$ \\
-Secondary \& more & \\
\hline Marital status & $63(21.8)$ \\
-Not married & $226(78.2)$ \\
-Married &
\end{tabular}

* skilled workers include farmer, builder, industrial, trade workers.

$\mathrm{HCV}$ cases. Xerostomia and pruritis were the most prevalent rheumatologic and dermatological manifestation respectively.

\section{II- Diabetes mellitus in chronic HCV cases}

The mean age of HCV diabetic cases $( \pm$ SD) $[48.1$ ( \pm 9.2)] was statistically significantly higher than that of HCV nondiabetics [40.7 $( \pm 10.4)](\mathrm{P}$ value $=0.001)$. Gender, level of education, marital status and occupation did not affect the incidence of diabetes among $\mathrm{HCV}$ cases ( $\mathrm{P}$ values $=0.90,0.35,0.13$ and 0.46 respectively). However, current residence did affect the incidence of DM. $85 \%$ of diabetic HCV cases and $65.5 \%$ of non diabetic $\mathrm{HCV}$ cases were from urban regions and this difference was statistically significant. Regarding special habits, diabetic HCV cases were more often found to smoke shisha \& drink alcohol than non diabetics (Table 2). However, they smoke less than nondiabetic $\mathrm{HCV}$ cases. The difference was statistically significant regarding alcohol drinking only.

Diabetic cases were more prone to have cirrhosis than nondiabetic $\mathrm{HCV}$ cases. Also their stage of liver fibrosis
Table 2 Sociodemograhic characteristics and special habits of diabetic and nondiabetic HCV cases

\begin{tabular}{|c|c|c|c|c|}
\hline \multirow[t]{2}{*}{ Parameters } & \multicolumn{2}{|l|}{ HCV Cases } & \multirow{2}{*}{$\begin{array}{l}\text { Total } \\
\mathrm{N}=289\end{array}$} & \multirow{2}{*}{$\begin{array}{l}P \text { - } \\
\text { value }\end{array}$} \\
\hline & $\begin{array}{l}\text { Non diabetic } \\
(\mathrm{N}=249) \\
\text { No }(\%)\end{array}$ & $\begin{array}{l}\text { Diabetic } \\
(\mathrm{N}=40) \\
\text { No }(\%)\end{array}$ & & \\
\hline \multicolumn{5}{|l|}{ Age (years) } \\
\hline- Mean \pm SD & $40.7 \pm 10.4$ & $48.1 \pm 9.2$ & $41.7 \pm 10.6$ & 0.001 \\
\hline -Range & $19-65$ & $29-65$ & $19-65$ & \\
\hline \multicolumn{5}{|l|}{ Gender } \\
\hline -Male & $178(71.5)$ & $29(72.5)$ & 207 (71.6) & 0.90 \\
\hline -Female & $71(28.5)$ & $11(27.5)$ & $82(28.4)$ & \\
\hline \multicolumn{5}{|l|}{ Current residence } \\
\hline -Urban & $163(65.5)$ & $34(85.0)$ & $197(68.2)$ & 0.01 \\
\hline -Rural & $86(34.5)$ & $6(15.0)$ & $92(31.8)$ & \\
\hline \multicolumn{5}{|l|}{ Level of education } \\
\hline -Less than secondary & $111(44.6)$ & $21(52.5)$ & $132(45.7)$ & 0.35 \\
\hline -Secondary \& more & $138(55.4)$ & $19(47.5)$ & $157(54.3)$ & \\
\hline \multicolumn{5}{|l|}{ Marital status } \\
\hline -Not married & $58(23.3)$ & $5(12.5)$ & $63(21.8)$ & 0.13 \\
\hline -Married & $191(76.7)$ & $35(87.5)$ & $226(78.2)$ & \\
\hline \multicolumn{5}{|l|}{ Occupation } \\
\hline -skilled workers & 77 (30.9) & $7(17.5)$ & $84(29.1)$ & \\
\hline -employee & $56(22.5)$ & $10(25.0)$ & $66(22.8)$ & \\
\hline - student & $3(1.2)$ & 0 & $3(1.0)$ & 0.46 \\
\hline -housewife & $46(18.5)$ & $13(32.5)$ & $59(20.4)$ & \\
\hline -others & $67(26.9)$ & $10(25.0)$ & $77(26.6)$ & \\
\hline Cigarette Smoking & $53(22.0)$ & $7(17.5)$ & $60(21.4)$ & 0.64 \\
\hline Shisha Smoking & $11(4.6)$ & $4(10.5)$ & $15(5.2)$ & 0.27 \\
\hline Alcohol Drinking & $2(0.8)$ & $3(7.9)$ & $5(7.0)$ & 0.02 \\
\hline
\end{tabular}

and inflammation was more severe than nondiabetic HCV cases. However, the difference was not statistically significant between diabetic and nondiabetic HCV cases regarding liver condition. There was no significant difference between diabetic and non diabetic HCV cases regarding the laboratory findings (Table 3 ).

\section{Case control study. HCV cases and non HCV controls}

The mean age of non diabetic HCV cases ( \pm Standard deviation) was 40.7 ( \pm 10.4$)$ with age range 19 to 65 years old which was less than the diabetic HCV cases. Their mean age ( \pm Standard deviation) was $48.1( \pm 9.2)$ with age range 29 to 65 years old. The mean age of non diabetic controls ( \pm Standard deviation) was $41.6( \pm$ 11.9) with age range 21 to 65 years old. Diabetic nonHCV controls were elder in age than non diabetic controls (Table 4). Table 4 also shows that age distribution, gender, current residence, level of education, and marital status differed significantly among HCV cases and nonHCV controls regarding diabetic groups. 
Table 3 Laboratory findings of diabetic and nondiabetic HCV cases

\begin{tabular}{|c|c|c|c|}
\hline \multirow[t]{2}{*}{ Laboratory findings } & \multicolumn{2}{|l|}{ HCV Cases } & \multirow[t]{2}{*}{ P-value } \\
\hline & $\begin{array}{l}\text { Non diabetic } \\
\text { No }(\%)\end{array}$ & $\begin{array}{l}\text { Diabetic } \\
\text { No (\%) }\end{array}$ & \\
\hline \multicolumn{4}{|l|}{ Abnormal Liver function } \\
\hline - High ALT & $174(76)$ & $34(89.5)$ & 0.06 \\
\hline - High AST & $170(75.2)$ & $24(64.9)$ & 0.18 \\
\hline - High ALKP & $21(19.1)$ & $5(25)$ & 0.76 \\
\hline - High BIL & $31(17.5)$ & $8(26.7)$ & 0.24 \\
\hline \multicolumn{4}{|l|}{ Abnormal Hemogram } \\
\hline - Anemia & $29(14.6)$ & $4(12.1)$ & 0.92 \\
\hline - Thrombocytopenia & $44(23.4)$ & $13(41.9)$ & 0.07 \\
\hline - Leukopenia & $48(24.9)$ & $9(27.3)$ & 0.99 \\
\hline - Neutropenia & $60(39.5)$ & $9(36.0)$ & 0.74 \\
\hline - Lymphopenia & $9(5.5)$ & $1(3.2)$ & 0.91 \\
\hline \multicolumn{4}{|l|}{ Autoimmune markers } \\
\hline - Positive ANA & $10(11.8)$ & $2(11.1)$ & 0.75 \\
\hline - Positive RF & $79(59.0)$ & $13(52.0)$ & 0.67 \\
\hline High Alpha-Feto protein & $21(21)$ & $3(3)$ & 1.00 \\
\hline High Blood GLUC & 0 & $40(100)$ & 0.0001 \\
\hline High Glycosylated Hb & $3(60)$ & $7(58.33)$ & 0.633 \\
\hline High TSH & $3(2.77)$ & 0 & 0.811 \\
\hline
\end{tabular}

Table 5 Blood sugar status of case and control study groups

\begin{tabular}{|c|c|c|c|c|}
\hline \multirow[t]{2}{*}{ Blood sugar status } & \multicolumn{2}{|c|}{ No of patients $\mathrm{N}^{\circ}(\%)$} & \multirow[t]{2}{*}{ Total } & \multirow[t]{2}{*}{ P-value } \\
\hline & Cases & Controls & & \\
\hline Diabetic & 40 (13.8) & $12(4.2)$ & $52(7.7)$ & 0.0001 \\
\hline Non diabetic & $249(86.2)$ & 277(95.8) & $526(92.3)$ & \\
\hline Total & $289(100)$ & $289(100)$ & $578(100)$ & \\
\hline
\end{tabular}

Regarding blood sugar status, it was found that 53 (7.7\%) patients were found to be diabetic while 638 (92.3\%) were non diabetic (Table 5). The difference was statistically significant $(\mathrm{P}=0.0001)$. Diabetic cases represented $13.8 \%$ of the HCV cases while diabetic controls represented $4.2 \%$ of the controls.

Abnormal high ALT, high ALKP and high BIL values was more frequently shown among $\mathrm{HCV}$ diabetic cases compared with $\mathrm{HCV}$ nondiabetic cases (Table 6). In non HCV controls, diabetic subjects less frequently showed high AST and ALT. The difference was statistically significant regarding the former parameters.

\section{HCV Diabetics and non HCV Diabetics}

The mean age of diabetic HCV cases $( \pm$ SD) was 48.1 ( \pm 9.1) with age range 29 to 65 years old. More than one

Table 4 Sociodemograhic characteristics of diabetic and nondiabetic HCV cases and diabetic and nondiabetic nonHCV controls

\begin{tabular}{|c|c|c|c|c|c|}
\hline \multirow[t]{2}{*}{ Parameters } & \multicolumn{2}{|l|}{ HCV Cases } & \multicolumn{2}{|l|}{ Controls } & \multirow[t]{2}{*}{ P-value } \\
\hline & $\begin{array}{l}\text { Non diabetic } \\
(\mathrm{N}=249) \\
\text { No }(\%)^{*}\end{array}$ & $\begin{array}{l}\text { Diabetic } \\
(\mathrm{N}=40) \\
\text { No }(\%)\end{array}$ & $\begin{array}{l}\text { Non diabetic } \\
(\mathrm{N}=277) \\
\text { No }(\%)^{*}\end{array}$ & $\begin{array}{l}\text { Diabetic } \\
(\mathrm{N}=12) \\
\text { No }(\%)\end{array}$ & \\
\hline \multicolumn{6}{|l|}{ Age (years) } \\
\hline- Mean \pm SD & $40.7 \pm 10.4$ & $48.1 \pm 9.2$ & $41.6 \pm 11.9$ & $48.6 \pm 8.4$ & 0.001 \\
\hline -Range & $19-65$ & $29-65$ & $21-65$ & $34-65$ & \\
\hline \multicolumn{6}{|l|}{ Age distribution } \\
\hline$-18-30$ & $52(20.9)$ & $2(5.0)$ & $65(23.5)$ & 0 & 0.0001 \\
\hline$-31-40$ & $68(27.3)$ & $7(17.5)$ & $75(27.1)$ & $2(16.7)$ & \\
\hline$-41-50$ & $81(32.5)$ & $15(37.5)$ & $70(25.3)$ & $4(33.3)$ & \\
\hline $51-60$ & $45(18.1)$ & $13(32.5)$ & $49(17.7)$ & $5(41.7)$ & \\
\hline -above 60 & $3(1.2)$ & $3(7.5)$ & $18(6.5)$ & $1(8.3)$ & \\
\hline \multicolumn{6}{|l|}{ Gender } \\
\hline -Male & $178(71.5)$ & $29(72.5)$ & $154(55.6)$ & $2(16.7)$ & 0.0001 \\
\hline -Female & $71(28.5)$ & $11(27.5)$ & $123(44.4)$ & $10(83.3)$ & \\
\hline \multicolumn{6}{|l|}{ Current residence } \\
\hline -Urban & $163(65.5)$ & $34(85.0)$ & 0 & 0 & 0.0001 \\
\hline -Rural & $86(34.5)$ & $6(15.0)$ & $277(100)$ & $12(100)$ & \\
\hline \multicolumn{6}{|l|}{ Level of education } \\
\hline -Less than secondary & $111(44.6)$ & $21(52.5)$ & $177(63.9)$ & $12(100)$ & 0.0001 \\
\hline -Secondary \& more & $138(55.4)$ & $19(47.5)$ & $100(36.1)$ & 0 & \\
\hline \multicolumn{6}{|l|}{ Marital status } \\
\hline -Not married & $58(23.3)$ & $5(12.5)$ & 44 (15.9) & $5(41.7)$ & 0.03 \\
\hline -Married & $191(76.7)$ & 35 (87.5) & 233(84. 1) & 7 (58.3) & \\
\hline
\end{tabular}


Table 6 Laboratory findings of HCV cases and controls

\begin{tabular}{|c|c|c|c|c|c|}
\hline \multirow[t]{2}{*}{ Parameter } & \multicolumn{2}{|c|}{ Cases } & \multicolumn{2}{|c|}{ Controls } & \multirow[t]{2}{*}{ P-value } \\
\hline & $\begin{array}{c}\text { Non diabetic } \\
\text { No }(\%)^{*}\end{array}$ & $\begin{array}{l}\text { Diabetic } \\
\text { No (\%) }\end{array}$ & $\begin{array}{c}\text { Non diabetic } \\
\text { No }(\%)^{*}\end{array}$ & $\begin{array}{l}\text { Diabetic } \\
\text { No (\%) }\end{array}$ & \\
\hline \multicolumn{6}{|c|}{ Abnormal Liver function } \\
\hline - High ALT & $174(76.0)$ & $34(89.5)$ & $24(8.9)$ & $1(8.3)$ & 0.001 \\
\hline - High AST & $170(75.2)$ & $24(64.9)$ & $15(5.5)$ & $1(8.3)$ & 0.001 \\
\hline - High ALKP & $21(19.1)$ & $5(25.0)$ & 0 & 0 & 0.02 \\
\hline •High BIL & $31(17.5)$ & $8(26.7)$ & 0 & 0 & 0.01 \\
\hline High Blood GLUC & 0 & $40(100)$ & 0 & $12(100)$ & 0.0001 \\
\hline
\end{tabular}

-third of cases fall in the age group 41 to 50 years old and $7.5 \%$ only above 60 years old (Table 7 ). The mean age of diabetic controls $( \pm$ SD) was $48.6( \pm 8.4)$ with age range 34 to 65 years old. Males represented $72.5 \%$ of the diabetic HCV cases but only $16.7 \%$ of diabetic controls. All of the controls were from rural areas while only $15 \%$ of the cases were from rural areas. None of the controls completed their secondary education while $47.5 \%$ of the cases did. Table 7 also shows that $87.5 \%$ of cases and $58.3 \%$ of the controls were married. The difference was statistically significant regarding the former parameters except the marital status.

Table 7 Sociodemograhic characteristics of diabetic HCV cases and nonHCV diabetic controls

\begin{tabular}{|c|c|c|c|}
\hline Parameters & $\begin{array}{l}\text { Diabetic HCV } \\
\text { cases } \\
(\mathrm{N}=40) \\
\mathrm{N}^{\circ}(\%)\end{array}$ & $\begin{array}{l}\text { Diabetic } \\
\text { Controls } \\
(\mathrm{N}=12) \\
\mathrm{N}^{\circ}(\%)^{*}\end{array}$ & $\begin{array}{l}\text { P- } \\
\text { value }\end{array}$ \\
\hline \multicolumn{4}{|l|}{ Age (years) } \\
\hline -Mean \pm SD & $48.1 \pm 9.1$ & $48.6 \pm 8.4$ & 0.001 \\
\hline -Range & $29-65$ & $34-65$ & \\
\hline \multicolumn{4}{|l|}{ Age distribution } \\
\hline$-18-30$ & $2(5.0)$ & 0 & 0.0001 \\
\hline$-31-40$ & $7(17.5)$ & $2(16.7)$ & \\
\hline$-41-50$ & $15(37.5)$ & $4(33.3)$ & \\
\hline $51-60$ & $13(32.5)$ & $5(41.7)$ & \\
\hline -above 60 & $3(7.5)$ & $1(8.3)$ & \\
\hline \multicolumn{4}{|l|}{ Gender } \\
\hline -Male & $29(72.5)$ & $2(16.7)$ & 0.0001 \\
\hline -Female & $11(27.5)$ & $10(83.3)$ & \\
\hline \multicolumn{4}{|l|}{ Current residence } \\
\hline -Urban & $34(85.0)$ & 0 & 0.0001 \\
\hline -Rural & $6(15.0)$ & $12(100)$ & \\
\hline \multicolumn{4}{|l|}{ Level of education } \\
\hline $\begin{array}{l}\text {-Less than } \\
\text { secondary }\end{array}$ & $21(52.5)$ & $12(100)$ & 0.008 \\
\hline -Secondary \& more & 19 (47.5) & 0 & \\
\hline \multicolumn{4}{|l|}{ Marital status } \\
\hline -Not married & $5(12.5)$ & $5(41.7)$ & 0.07 \\
\hline -Married & $35(87.5)$ & $7(58.3)$ & \\
\hline
\end{tabular}

Regarding abnormal lab characteristics, Table 8 shows that HCV cases were more likely to have high ALT (89.5\%) and AST (64.9\%) than non HCV controls $(8.3 \%$ each).

\section{Discussion}

Several strands of evidence have suggested a possible link between $\mathrm{HCV}$ infection and an increased prevalence of Type2D [20]. Based on case-control studies, the prevalence of DM had been reported in $21 \%$ to $50 \%$ (a two- to ten-fold increase in prevalence) of patients with chronic HCV infection, which was significantly higher than that in the general population or among patients with other forms of liver diseases [21]. This study showed that $13.84 \%$ of the HCV patients were type 2 diabetics. These results are comparable to the results of the findings reported by Petit et al. [22], Wang et al. [23] and Veldt et al. [24]. Other authors reported higher numbers of diabetics in their studies on $\mathrm{HCV}$ patients as El-Zayadi et al. [17] \& Lecube et al. [25]. They reported prevalence of DM to be $20.9 \%-29 \%$ among HCV patients. Prevalences ranging between $32.5 \%$ and $39.8 \%$ were reported by Zhao et al. [26] and Chehadeh et al. [14]. Differences in the criteria employed in the diagnosis of DM, source of controls, case definition, sample size and underlying target population may explain much of this observed variability among studies.

Diabetes was shown to be prevalent in $4.15 \%$ of the controls who represent age-matched normal population. This result (among controls) is 3-4 times less than what was found in this study (among HCV cases), indicating that $\mathrm{HCV}$ patients are a high risk population for DM. In contrast, some studies provided evidence against

Table 8 Abnormal Lab characteristics of diabetic cases and diabetic controls

\begin{tabular}{llll}
\hline Parameters & $\begin{array}{l}\text { Diabetic HCV cases } \\
\mathbf{N}=\mathbf{4 0} \\
\mathbf{N}^{\circ}(\%)\end{array}$ & $\begin{array}{l}\text { Diabetic Controls } \\
\mathbf{N}=\mathbf{1 2} \\
\mathbf{N}^{\circ}(\%)^{*}\end{array}$ & \begin{tabular}{l} 
P-value \\
\hline High ALT
\end{tabular} \\
\hline High AST & $24(89.5)$ & $1(8.3)$ & $\mathbf{0 . 0 0 1}$ \\
\hline High Blood GLUC & $40(100)$ & $1(8.3)$ & $\mathbf{0 . 0 0 1}$ \\
\hline
\end{tabular}


potential association between these two disorders [27]. The prevalence of diabetes in adults in Egypt ranged from $5 \%$ in rural communities in the Nile delta to $10 \%$ in lower socioeconomic areas of Cairo and over $20 \%$ in higher socioeconomic areas in Cairo [28]. Similar results were reported from Italy and India [29,30]. Higher prevalences of DM were reported from other authors $[6,26]$. This may be attributed to differences in environmental influences, genetic susceptibility and diets.

\section{Sociodemographic characters and special habits of cases and controls}

It was noticed that the highest percentage of diabetes (37.5\%) was among age group from 41-50 years which was similar to that reported by Wang et al. [23]. Conversely, others stated that older age was a potential risk factor for development of DM in HCV patients [31]. It is interesting to note that older age is associated with more severe liver disease among HCV-infected patients [32]. Studies from Italy and USA referred that HCV increases the prevalence of DM independently of age $[33,34]$. These findings have some important clinical and public health implications. They imply that the younger the persons with $\mathrm{HCV}$ infection, the greater the risk that they will develop diabetes than will their age-group counterparts without HCV infection. Therefore, screening for and prevention of diabetes in persons with $\mathrm{HCV}$ infection could be started earlier than the suggested age of $\geq 45$ years for the general population [19], especially for those with higher body mass index levels or with other risk factors for diabetes. In addition, young adults with diabetes in communities with a high prevalence of $\mathrm{HCV}$ infection could be tested for an underlying $\mathrm{HCV}$ infection.

The mean age for $\mathrm{HCV} \mathrm{DM}+$ was higher than the mean age for HCV DM- subjects which is interestingly similar to the findings of Giordanino and coworkers [35]. These findings support the idea that the induction of diabetes in $\mathrm{HCV}$ patients is progressive rather than abrupt [14]. Other studies suggest that HCV interferes with glucose metabolism independently of age [21,24].

Diabetes was more prevalent in females than in males. Our findings are similar to that reported by Huang et al. [31]. Males may be more frequently exposed to $\mathrm{HCV}$ infection because they have more risk factors including schistosomal infection, shaving beards, accidents, and exposure to operations and blood transfusions [36]. Otherwise, women might be more likely to be associated with HCV clearance and lower rates of HCV-RNA positivity [37]. However, there was no significant difference between diabetic and non-diabetic cases regarding gender which was similar to other studies [24,33]. Persons with type $2 \mathrm{DM}$ tended to have lower educational attainment [38]. This is in concordance with our study.
Habitual smoking is a well-documented risk factor for exacerbation of liver conditions, such as increased alanine transferase levels and increased fibrosis that would increase the likelihood of type 2 diabetes [39]. There was a history of cigarette smoking among $42.2 \%$ of $\mathrm{HCV}$ subjects which is similar to that reported by Eissa et al. [36]. Our study revealed that HCV cases who were current cigarette smokers were more likely to be diabetic (17.5\%) than current shisha or goza smokers (10.5\%). Cases who had a history of cigarette smoking (50\%) were more likely to be diabetic than those with history of shisha smoking (16.4\%). That was in concordance with findings of Alavian et al. [40]. Yet smoking was not a significant predicting factor for diabetes which was similar to results of Wang et al. [23].

Hepatitis $\mathrm{C}$ and excessive alcohol consumption are not likely to have an additive effect in relation to the risk of having diabetes [23]. Only $24.6 \%$ of the HCV subjects in this study had a history of drinking alcohol and 7.9\% were current alcoholics. Current alcohol drinking was a significant risk factor for developing DM which was in agreement with and Ryu et al. [41] findings.

\section{Liver condition}

Patients with HCV-related liver cirrhosis are associated with a significantly higher prevalence of DM than those cirrhotic patients with other etiologies [42]. This is on line with our study. This study showed that $23.1 \%$ of $\mathrm{HCV}$ cirrhotics were diabetic which was similar to the findings of other authors [35]. Higher figures were reported by Kwon et al. [43]. The discrepancies among studies may be explained by severity of liver disease. In another remarkable study, in which cirrhotic $\mathrm{HCV}$ patients were carefully excluded, a third of them had diabetes [44]. On excluding cirrhotic patients from the HCV cases in this study, $12.5 \%$ of the cases had DM which was 4 times the prevalence in the controls representing the normal Egyptian population. Of interest, that was consistent with a study on a large cohort of patients conducted by Lecube and coworkers [25]. Taken together these findings suggest that HCV infection is a more important predictor of glucose intolerance than cirrhosis, and the combination of both factors further increases the risk of diabetes. Other factors than cirrhosis must be found to explain the increased prevalence of DM in HCV patients [22].

Regarding other sonographic features, anti-HCV-positive subjects with sonographic evidence of bright liver, enlarged liver and chronic liver disease had a higher prevalence of $\mathrm{T} 2 \mathrm{D}$ compared with patients whose sonographic features were normal. The trend of increasing prevalence of T2D with severity of sonographic stages in anti-HCV-positive subjects implies that viral inflammatory activity, time duration, insulin secretion, insulin sensitivity, and the interaction with other well-known 
diabetes risk factors appear to play an important role in the development of T2D.

Diabetes is associated with increased fibrosis in chronic HCV but such an association may be related to the high prevalence of diabetes in patients with cirrhosis [45]. The frequency of diabetes mellitus increased along with pathological staging [24]. The fibrosis score was higher in diabetic HCV patients [15]. The results hereafter were on line with that. In this study, none of the diabetic patients had normal stage of fibrosis. Nearly one half of the diabetic patients (46.7\%) showed moderate to severe fibrosis compared to $34.7 \%$ in non diabetic $\mathrm{HCV}$ patients. The discrepancies among studies may be explained by differences in ethnic background, HCV genotype frequency, and duration and severity of liver disease.

Liver biopsy specimens of diabetic HCV patients showed higher inflammatory activity defined by histological activity index score than the nondiabetic $\mathrm{HCV}$ group for moderate and severe stages. That is in line with the results reported by several authors [46]. HCV patients who develop diabetes had more severe liver disease according to both their liver enzymes and biopsy findings [22]. These observations suggest that not $\mathrm{HCV}$ infection itself but the resultant ongoing inflammation of the liver might determine a higher risk for DM. Patients with an earlier stage of chronic HCV infection have $\beta$-cell dysfunction but diabetes does not become established until cirrhosis has supervened [47]. This could explain the negative association between stage of inflammation (found to be normal) and DM manifest in this series.

Blood picture did not differ between the $2 \mathrm{HCV}$ groups. This study was in keeping with the findings of other authors [44]. There was at least one abnormal feature in the hemogram of $68.6 \%$ of the $\mathrm{HCV}$ cases.

Individuals with type 2 diabetes have a higher incidence of liver function test (LFT) abnormalities than individuals who do not have diabetes [48] which is similar to our findings. However, Chehadeh et al. [14] found no difference in this aspect. Interestingly, diabetic controls in this study had higher mean values of ALT than nondiabetic controls. Studies on European diabetics showed the same results in Greece [49] and Spain [25].

\section{Conclusion}

Despite the close relationship between $\mathrm{HCV}$ infection and DM, The underlying mechanism(s) that links diabetes and $\mathrm{HCV}$ infection remains conjectural. The increased prevalence of diabetes in chronic hepatitis is unique to $\mathrm{HCV}$ and therefore that unique mechanisms may underlie glucose intolerance in HCV patients. Type $2 \mathrm{DM}$ is a complex, multisystem disease with a pathophysiology that includes a defect in insulin secretion, increased hepatic glucose production, and resistance to the action of insulin, all of which contribute to the development of overt hyperglycemia. In addition, obesity, aging, and genetic factors such as family history of DM all may contribute to the development of type 2 DM. All these factors make it difficult to evaluate the pathogenic role of $\mathrm{HCV}$ infection in the development of type $2 \mathrm{DM}$.

Our findings that a more severe inflammatory and fibrotic process were associated with diabetes suggest that the pathogenesis of DM in HCV infection may be multifactorial- a precirrhotic state leading to an abnormal glucose metabolism and insulin resistance, acting in conjunction with undefined pancreatic damage, occurring in genetically prone patients is an explanation. Another possible explanation, as proposed by Caronia et al [47], is that $\beta$-cell responsiveness is impaired in patients with $\mathrm{HCV}$, possibly because of direct viral effects on $\beta$-cell function. Thus for a given degree of liver dysfunction-and presumably IR, diabetes would be more likely to occur in patients with HCV.

In our study, the diabetic patients in the $\mathrm{HCV}$ group were older, more likely to have a history of alcohol drinking than the non diabetic $\mathrm{HCV}$ cases, factors that could potentially contribute to the development of type 2 diabetes. Logistic regression analyses showed that age and residence in urban regions were the predictive variables that could be associated with the presence of diabetes. Alcohol consumption was not a significant factor.

Abbreviations
HCV: Hepatitis C Virus; DM: diabetes mellitus; T2DM: Type 2 diabetes; EH:
Extrahepatic; ALT: Alanine transaminase; ALKP: Alkaline phosphatase; BIL:
Bilirubin; AST: Aspartate transferase; ADA: American Diabetes Association.

Author details

${ }^{1}$ Microbiology Department, Faculty of Pharmacy, Minia University, Minia, Egypt. ${ }^{2}$ Molecular Biology Unit, Viral Hepatitis Research Laboratory, (VHRL). 10 Kasr Elainy Street, Cairo, Egypt. ${ }^{3}$ Community, Environmental and Occupational Medicine Department, Faculty of Medicine, Ain Shams University, Cairo, Egypt. ${ }^{4}$ Tropical Diseases Department, Faculty of Medicine, Cairo University, Cairo, Egypt.

\section{Authors' contributions}

ElE: Acquisition, analysis and interpretation of data, performed statistical analysis, and practical laboratory work.

GFM: Revising the manuscript for intellectual content.

MED: Carried out practical laboratory work.

FAM: Designer and Primary investigator of the study, performed statistical analysis, and revising the manuscript for intellectual content.

GE: Participated in design and coordination and carried out all clinical aspects of the study.

MAH: Participated in design and coordination and revising the manuscript for intellectual content

All authors read and approved the final manuscript.

\section{Competing interests}

The authors declare that they have no competing interests.

Received: 11 January 2011 Accepted: 26 July 2011

Published: 26 July 2011 


\section{References}

1. Mastoi AA, Devrajani BR, Shah SZ, Rohopoto Q, Memon SA, Baloch M, Qureshi GA, Sami W: Metabolic investigations in patients with hepatitis B and C. World J Gastroenterol 2010, 16(5):603-7.

2. Medhat A, Shehata M, Magder S: Hepatitis C in a community in Upper Egypt: Risk factors for infection. Am J Trop Med Hyg 2002, 66:633-8.

3. Ray SC, Arthur RR, Carella A, Bukh J, Thomas DL: Genetic epidemiology of HCV throughout Egypt. J Infect Dis 2000, 182:698-707.

4. Frank C, Mohamed MK, Strickland GT, Lavanchy D, Arthur RR, Magder LS, ElKholy T, Abdel-Wahab Y, Aly Ohn ES, Anwar W, Sallam L: The role of parentral antischistosomal therapy in the spread of HCV in Egypt. Lancet 2000, 355:887-91.

5. Cacoub P, Renou C, Rosenthal E, Cohen P, Loury I: EH manifestations associated with HCV infection. A prospective multicenter study of 321 patients. The GERMIVIC Groupe d'Etude et de Recherche en Medicine Interne et Maladies Infectieuses sur le Virus de I'Hepatite C. Medicine [Baltimore] 2000, 79:47-56.

6. Mehta SH, Brancati FL, Sulkowski MS, Strathdee S, Szklo M, Thomas DL: Prevalence of type 2 diabetes mellitus among persons with hepatitis $C$ virus infection in the United States. Ann Intern Med 2000, 133:592-599.

7. Antonelli A, Ferri C, Fallahi P, Ferrari SM, Ghinoi A, Rotondi M, Ferrannini E: Thyroid disorders in chronic hepatitis C virus infection. Thyroid 2006, 16(6):563-72.

8. Sanzone AM, Bégué RE: Hepatitis $C$ and arthritis: an update. Infect Dis Clin North Am 2006, 20(4):877-89.

9. El-Serag H, Hampel H, Yeh C, Rabeneck L: EH manifestations of hepatitis C among U.S. male veterans. Hepatology 2002, 36:1439-45.

10. Pyrsopoulos NT, Reddy KR: Extrahepatic manifestations of chronic viral hepatitis. Curr Gastroenterol Rep 2001, 3(1):71-8, Review.

11. Zimmet P, Alberti KG, Shaw J: Global and societal implications of the diabetes epidemic. Nature 2001, 414:782-7.

12. Sone H, Tanaka S, limuro S, Tanaka S, Oida K, Yamasaki Y, Oikawa S, Ishibashi S, Katayama S, Yamashita H, Ito H, Yoshimura Y, Ohashi Y, Akanuma Y, Yamada N, Japan Diabetes Complications Study Group: Longterm lifestyle intervention lowers the incidence of stroke in Japanese patients with type 2 diabetes: a nationwide multicentre randomised controlled trial (the Japan Diabetes Complications Study). Diabetologia 2010, 53(3):419-28

13. Meisinger C, Thorand B, Schneider A, Stieber J, Döring A, Löwel H: Sex differences in risk factors for incident type 2 diabetes mellitus: the MONICA Augsburg cohort study. Arch Intern Med 2002, 14;162(1):82-9.

14. Chehadeh W, Abdella N, Ben-Nakhi A, Al-Arouj M, Al-Nakib W: Risk factors for the development of diabetes mellitus in chronic hepatitis $C$ virus genotype 4 infection. J Gastroenterol Hepatol 2009, 24(1):42-8.

15. Loaeza-del Castillo A: Association between diabetes, overweight, obesity and dyslipidemia with fibrosis progression in chronic hepatitis $C$ patients. 40th EASL. April13-17, 2005. Paris, France 581

16. Schattner $\mathrm{A}$, Knobler $\mathrm{H}$ : Clinical aspects of chronic hepatitis $\mathrm{C}$ infection. JAMA 2003, 290(11):1453 author reply 1453-4.

17. El-Zayadi AR, Selim OE, Hamdy H, Dabbous H, Ahdy A, Moniem SA: Association of chronic hepatitis $C$ infection and diabetes mellitus. Trop Gastroenterol 1998, 19(4):141-4

18. Abdel-Hamid M, Edelman DC, Highsmith WE, Constantine NT: Optimization, assessment, and proposed use of a direct nested reverse transcription-polymerase chain reaction protocol for the detection of hepatitis C virus. J Hum Virol 1997, 1(1):58-65.

19. ADA American Diabetes Association: Diagnosis and classification of Diabetes Mellitus. Diab Care 2008, 31, S1, S55-S60.

20. Kaabia N, Ben Jazia E, Slim I, Fodha I, Hachfi W, Gaha R, Khalifa M, Hadj Kilani A, Trabelsi H, Abdelaziz A, Bahri F, Letaief A: Association of hepatitis $C$ virus infection and diabetes in central Tunisia. World J Gastroenterol 2009, 15(22):2778-81

21. Negro F, Alaei M: Hepatitis C virus and type 2 diabetes. World J Gastroenterol 2009, 15(13):1537-1547.

22. Petit JM, Bour JB, Galland-Jos C, Minello A, Verges B, Guiguet M: Risk factors for diabetes mellitus and early insulin resistance in chronic hepatitis C. J Hepatology 2001, 35:279-283.

23. Wang CS, Wang ST, Yao WJ, Chang TT, Chou P: Hepatitis C virus infection and the development of type 2 diabetes in a community-based longitudinal study. Am J Epidemiol 2007, 166(2):196-203.
24. Veldt BJ, Chen W, Heathcote EJ, Wedemeyer H, Reichen J, Hofmann WP, de Knegt RJ, Zeuzem S, Manns MP, Hansen BE, Schalm SW, Janssen HL: Increased risk of hepatocellular carcinoma among patients with hepatitis C cirrhosis and diabetes mellitus. Hepatology 2008, 47(6):1856-62.

25. Lecube A, Hernandez C, Genesca J, Esteban J: Diabetes is the main factor accounting for the high ferritin levels detected in chronic HCV infection. Diabetes Care 2004, 27(11):2669-75.

26. Zhao $\mathrm{P}$, Wang JB, Jiao J: Investigation on the incidence of diabetes in chronic hepatitis $C$ patients and their HCV genotypes. Zhonghua Gan Zang Bing Za Zhi 2006, 14(2):86-8.

27. Del Olmo JA, Serra MA, Rodrigo JM: Liver cirrhosis and DM. J Hepatol 1996, 24:645.

28. Herman WH, Ali MA, Aubert RE, Engelgau MM, Kenny SJ, Gunter EW, Malarcher AM, Brechner RJ, Wetterhall SF, DeStefano F, Thompson TJ, Smith PJ, Badran A, Sous ES, Habib M, Hegazy M, abd el Shakour S, Ibrahim AS, el Moneim el Behairy A: Diabetes mellitus in Egypt: risk factors and prevalence. Diabet Med 1995, 12:1126-1131.

29. Garancini P, Gallus G, Calori G, Formigaro F, Micossi P: Incidence and prevalence rates of diabetes mellitus in Italy from routine data: a methodological assessment. Eur J Epidemiol 1991, 7(1):55-63.

30. Sadikot SM, Nigam A, Das S, Bajaj S, Zargar AH, Sosale A: The burden of diabetes and impaired glucose tolerance in India using the WHO 1999 criteria: prevalence of diabetes in India Study (PODIS). Diabetes Res Clin Pract 2004, 66:301

31. Huang JF, Dai CY, Hwang SJ, Ho CK: Hepatitis C viremia increases the association with type $2 \mathrm{DM}$ in a Hepatitis $B$ and $C$ endemic area: an epidemiological link with virological implication. Am J Gastroenterol 2007, 102(6):1237-43.

32. Hourigan LF, Macdonald GA, Purdie D: Fibrsis in chronic hepatitis C correlates significantly with body mass index and steatosis. Hepatology 1999, 29:1215-1219.

33. Custro N, Carrocio A, Ganci A, Scafidi V, Campagna P, Di Prima L, Monalto G: Glycemic homeostasis in chronic viral hepatitis and liver cirrhosis. Diabetes Metab 2001, 27(4Pt1):476-81.

34. Wilson C: Hepatitis C infection \& type 2 D in American-Indian women. Diab Care 2004, 27(9):2116-9.

35. Giordanino C, Bugianesi E, Smedile A, Ciancio A, Abate ML, Olivero A, Pellicano R, Cassader M, Gambino R, Bo S, Ciccone G, Rizzetto M, Saracco G: Incidence of type 2 diabetes mellitus and glucose abnormalities in patients with chronic hepatitis $C$ infection by response to treatment: results of a cohort study. Am J Gastroenterol 2008, 103(10):2481-7.

36. Eissa NA, Ghonaim M, EIBanna H, Bakr A, Mostafa MS, Shoeib S, AbdelMoteleb T: HCV-related chronic liver disease co-factors that determine the severity and prognosis. Egy J Med Microbiol 2003, 12(1):123-33.

37. Narciso-Schiavon JL, Schiavon LL, Carvalho-Filho RJ, Freire FC, Cardoso JR, Bordin JO, Silva AE, Ferraz ML: Anti-hepatitis C virus-positive blood donors: are women any different? Transfus Med 2008, 18(3):175-83.

38. Corrêa da Costa LM, Mussi AD, Brianze MR, Souto FJ: Hepatitis $C$ as a risk factor for diabetes type 2: lack of evidence in a hospital in central-west Brazil. Braz J Infect Dis 2008, 12(1):24-6.

39. Wang CS, Wang ST, Chang TT: Smoking and alanine transferase levels in hepatitis C: implications for prevention of HCV progression. Arch Intern Med 2002, 162:811-15.

40. Alavian SM, Hajarizadeh B, Nematizadeh F, Larijini B: Prevalence and determinants of diabetes mellitus among Iranian patients with chronic liver disease. BMC Endocr Disorders 2004, 4(1):4.

41. Ryu JK, Lee SB, Hong SJ, Lee S: Association of chronic hepatitis C virus infection and DM in Korean patients. Korean J Intern Med 2001, 16(1):18-23.

42. Gumber SC, Chopra S: Hepatitis C: a multifaceted disease. Review of EH manifestations. Ann Intern Med 1995, 123:615-20.

43. Kwon SY, Kim SS, Kwon KA, Chung MG, Park DK, Kim YS, Koo YS, Kim YK, Choi DJ, Kim JH: Prognostic significance of glycaemic control in patients with HBV \& HCV-realated cirrhosis \& DM. Diab Med 2005, 22(11):1530.

44. Knobler H, Schihmanter R, Zifroni A, Fenakel G, Schattner A: Increased risk of type 2 diabetes in non-cirrhotic patients with chronic hepatitis $C$ virus infection. Mayo Clin Proc 2000, 75:355-359.

45. Papatheodoridis GV, Savvas S, Petraki K, Manesis EK: DM in chronic hepatitis B \& C: prevalence \& potential association with the extent of liver fibrosis. J Vir Hep 2006, 13(5):303-10. 
46. Kuriyama S, Miwa Y, Nagaki M, Shiraki M, Toda K, Tomita E: Prevalence of diabetes and incidence of angiopathy in patients with chronic viral liver disease. J Clin Biochem Nutr 2007, 40:116-22.

47. Caronia S, Taylor K, Pagliaro L, Carr Z, Palazzo U, Petrik Jl: Further evidence for an association between noninsulin-dependent diabetes mellitus and chronic hepatitis C virus infection. Hepatology 1999, 30:1059-1063.

48. Harris MI: Elevated liver function tests in type II DM. Clin Diabetes 2005, 23(3):115-19.

49. Sortiropoulos A, Peppas TA, Skliros E, Pappas SI, Kotsini V, Apostolou O: Low prevalence of HCV infection in Greek diabetic patients. Diab Med 1999, $16: 250-2$.

doi:10.1186/1743-422X-8-367

Cite this article as: Elhawary et al: Association of HCV with diabetes

mellitus: an Egyptian case-control study. Virology Journal 2011 8:367.

\section{Submit your next manuscript to BioMed Central} and take full advantage of:

- Convenient online submission

- Thorough peer review

- No space constraints or color figure charges

- Immediate publication on acceptance

- Inclusion in PubMed, CAS, Scopus and Google Scholar

- Research which is freely available for redistribution

Submit your manuscript at www.biomedcentral.com/submit
() Biomed Central 